David Cole of Georgetown Univesity was presented with the Gladys M. Kammerer Award for No Equal Justice: Race and Class in the American Criminal Justice System (The New Press). The Kammerer prize is give for the best book in the field of U.S. national policy.

The Victoria Schuck Award for the best book published in 1999 on women and politics went to Judith
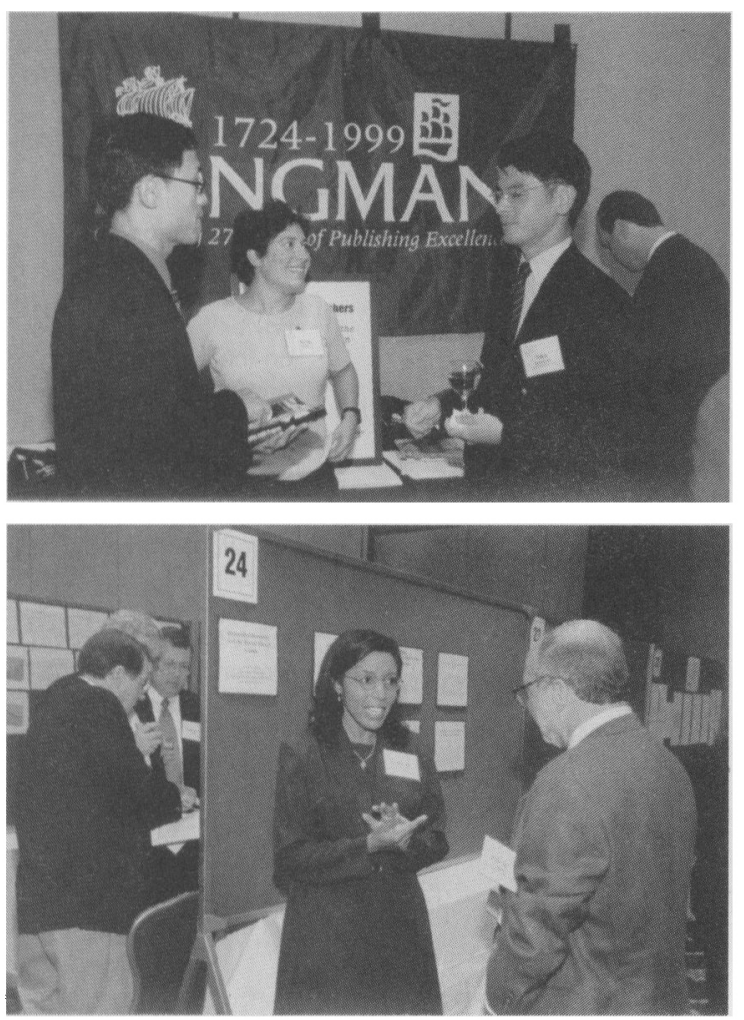

Building community. (From top) The first APSA welcome reception brought together graduate students, international participants, and first-time attendees. Poster sessions allow presenters and attendees to hold more in-depth conversations on research.

Baer of Texas A\&M University for her work, Our Lives before the Law; Constructing a Feminist Jurisprudence (Princeton University Press).

Barry O'Neill of Stanford University was awarded the Woodrow Wilson Foundation Award for Honor, Symbols, and War (University of Michigan Press). The Woodrow Wilson Foundation Award goes to the author of the best book published in 1999 on government, politics, or international affairs.

Full citations for all awards appear in the Gazette section of this issue. For details on the awards process for 2001, visit www.aspanet.org/ about/awards.

\section{Addison Wesley Longman Hosts the First Welcome and Orientation Reception at the Annual Meeting}

President Robert Keohane and Annual Meeting Program Co-Chairs Ira Katznelson and Helen Milner welcomed graduate students, international visitors, and first-time attendees to the first Annual Meeting Welcome and Orientation Reception on August 30. Addison Wesley Longman Publishing generously sponsored the event. Many Council members, 2000-01 APSA President Robert Jervis, and incoming President-Elect Robert Putnam were among those on hand to help orient the crowd to the Annual Meeting.

The Welcome and Orientation Reception was designed to introduce attendees to the intricacies of a very large meeting and to make sure that people had an opportunity to get acquainted with APSA leadership and staff. The reception drew a large crowd, presented each attendee with the opportunity to meet with other attendees and ask questions. APSA hopes to make this an annual event.

\section{Ralph Bunche Students Exhibit Work during Annual Meeting}

Eleven students from a talented class of 20 were chosen to present their work in a poster session at APSA's 2000 Annual Meeting. The students and their projects were:

Adan Balboa, St. Mary's University (TX): "Behind the Burro: Applying Dawson's Theories of Utility Heuristic and Linked Fate to Mexican Americans"

Yashica Danridge, Howard University: "The Influence of Age and Socioeconomic Status on the Support of an Independent Black Political Party"

\section{Nearly 1300 Annual Meeting Papers Now Available Online; Project Must Be Self-Sustaining by Next Year}

Papers from the 2000 Annual Meeting are now available online at http://pro.harvard.edu. The invitation to submit their papers to PROceedings: Political Research Online, the online collection of APSA Annual Meeting papers, was heeded by almost 1300 paper authors.

The paper submission site opened on July 1 and closed on September 3, the last day of the Annual Meeting. The 2000 papers, which can be searched by title or keyword, will remain online through August 2001, when the 2001 papers will be made available.

PROceedings, which is supported by a grant from The Andrew W. Mellon Foundation, is a collaborative effort of APSA and Harvard University Library under the direction of William J. Ball of The College of New Jersey. The project aims to continue Annual Meetings beyond their settings, to disseminate political science research more broadly and directly, to encourage the instructional use of recent research, and to facilitate individual and library access to the meeting papers.

PROceedings must be self-supporting by Spring of 2001, as this is the last year that PROceedings will be supported by the Mellon Foundation grant. APSA and its partners have engaged three consultants who will make recommendations to the APSA Council on the project's business plan. Current options for raising the revenue necessary to sustain the project include one or more of the following: increasing membership fees, increasing meeting registration fees, charging a paper submission fee, and/or charging a proposal submission fee. APSA is exploring the possibility of having a commercial vendor print individual copies of conference papers on demand on-site at the meeting. If feasible, such a service would be offered in lieu of the traditional panel paper room.

Take the opportunity to view the PROceedings site. If you have any questions or comments about the PROceedings project, please write to proceedings@apsanet.org. 